\title{
Ion-Molecule Reactions in Methylamine and Dimethylamine and Trimethylamine Systems
}

\author{
Jan A. Herman, * Kazimiera Herman,* and Terry B. McMahon \\ Department of Chemistry and Guelph-Waterloo Center for Graduate Work in Chemistry, University of \\ Waterloo, Ontario, Canada
}

\begin{abstract}
Fourier transform ion cyclotron resonance mass spectrometry has been used to measure the reaction rates for ions derived from methylamine with dimethylamine or trimethylamine. The use of the selective ion ejection technique greatly simplifies the elucidation of the ion-molecule reaction channels. The rate constants for proton transfer from protonated methylamine, $\mathrm{CH}_{3} \mathrm{NH}_{3}^{+}(\mathrm{m} / z$ 32), to dimethylamine and trimethylamine are $16.1 \pm 1.6 \times$ $10^{-10}$ and $9.3 \pm 0.9 \times 10^{-10} \mathrm{~cm}^{3}$ molec $^{-1} \mathrm{~s}^{-1}$, respectively. The rate constants for charge transfer from methylamine molecular ion, $\mathrm{CH}_{3} \mathrm{NH}_{2}^{+}(m / z 31)$, to dimethylamine and trimethylamine are $9.3 \pm 1.8 \times 10^{-10}$ and $15.0 \pm 5 \times 10^{-10} \mathrm{~cm}^{3} \mathrm{molec}^{-1} \mathrm{~s}^{-1}$, respectively. (J Am Soc Mass Spectrom 1991, 2, 220-225)
\end{abstract}

A s recently shown, the slow nucleophilic substitution reactions of protonated monoalkylamines [1] are in competition with fast proton transfer processes to dialkylamines and trialkylamines, which are the usual impurities $(\leq 1 \%)$ in the main reactant. In the study of the nucleophilic substitution reaction in methylamine:

$$
\mathrm{CH}_{3} \mathrm{NH}_{3}^{+}+\mathrm{CH}_{3} \mathrm{NH}_{2} \rightarrow\left(\mathrm{CH}_{3}\right)_{2} \mathrm{NH}_{2}^{+}+\mathrm{NH}_{3}
$$

it was assumed that this reaction occurs with a rate constant approximately two orders of magnitude lower than the proton transfer processes to dimethylamine and trimethylamine impurities:

$$
\mathrm{CH}_{3} \mathrm{NH}_{3}^{+}+\left(\mathrm{CH}_{3}\right)_{2} \mathrm{NH} \rightarrow\left(\mathrm{CH}_{3}\right)_{2} \mathrm{NH}_{2}^{+}+\mathrm{CH}_{3} \mathrm{NH}_{2}
$$

$$
\mathrm{CH}_{3} \mathrm{NH}_{3}^{+}+\left(\mathrm{CH}_{3}\right)_{3} \mathrm{NH} \rightarrow\left(\mathrm{CH}_{3}\right)_{3} \mathrm{NH}^{+}+\mathrm{CH}_{3} \mathrm{NH}_{2}
$$

In any realistic kinetic study of nucleophilic displacement reactions one has to take into account the presence of these impurities, because even small amounts of dimethylamine or trimethylamines contributing to the formation of methylated ion products will play a crucial role in measurements of the rate constant of reaction 1 . Some rate constants for proton transfer processes from methylamine molecular ion or its fragment ions to neutral methylamine to form the corresponding protonated ion species $(m / z$ 32) have

*Visiting Scientists 1989. Permanent address: Département de Chimie, Université Laval, Québec, Québec, Canada, G1K 7P4.

Address reprint requests to Jan A. Herman, Department of Chemistry, Laval University, Ste-Foy, Quebec, Canada G1K 7P4. been previously measured [2-9], and are summarized in Table 1. Clearly these rate constant values are scattered over a factor of two, which seems to be outside the normally admissible experimental error. To date, kinetics of proton transfer between different alkylamines have not been reported; however, generally it has been stated that these processes are very fast, probably occurring at or near the collision rate [10].

In this article we report kinetic data for reactions between methylamine and its fragments with methylamine in order to determine whether the rate constants are closer to the collision rate predicted by trajectory calculation [11], or whether they are nearer the values of $10^{-10} \mathrm{~cm}^{3}$ molec $^{-1} \mathrm{~s}^{-1}$ as measured by Munson [2]. In addition, we report kinetic data for reactions of ions derived from methylamine with dimethylamines and trimethylamines. These data may then be used to deduce the level of impurities in alkylamines and to determine the occurrence, or lack thereof, of the nucleophilic displacement reaction (1).

\section{Experimental}

All measurements in this study were carried out at ambient temperature $\left(-23^{\circ} \mathrm{C}\right)$ on a Spectrospin CMS-47 Fourier transform ion cyclotron resonance (FT-ICR) spectrometer [12, 13]. Pure compounds or mixtures in known ratio of amines were introduced into the ICR cell through a heated inlet controlled by a manual precision leak valve. The pressure of the reactants in the cell measured with a Balzers UHV ionization gauge was always $-3 \times 10^{-8}$ mbar. The application of the radio frequency resonance ejection technique to all undesired ion species allowed the isolation of a single ionic species in the ICR cell, and the 
Table 1. Rate constants for the formation of protonated methylamine ( $\mathrm{m} / z \mathrm{z}$ ) in unit: $10^{-10} \mathrm{~cm}^{3} \mathrm{molec} \mathrm{c}^{-1} \mathrm{~s}^{-1}$

\begin{tabular}{|c|c|c|c|c|c|c|c|}
\hline & Ref 2 & $R e f 3$ & $\operatorname{Ref} 4$ & Ref 5 & $\operatorname{Ref} 6^{a}$ & $\operatorname{Ref} 7^{\mathrm{h}}$ & Ref $\mathbf{8}^{c}$ \\
\hline$\overline{\mathrm{CH}_{3} \mathrm{~N}_{2}+\mathrm{CH}_{3} \mathrm{NH}_{2}}$ & $9 \pm 1$ & 16 & 19 & $14+3$ & $12+0.8$ & $20 \pm 5$ & 16.4 \\
\hline $\mathrm{CH}_{2} \mathrm{NH}_{2}^{+}+\mathrm{CH}_{3} \mathrm{NH}_{2}$ & 7 & 6 & 12 & $4 \pm 1$ & $11 \pm 1$ & $20 \perp 5$ & - \\
\hline $\mathrm{CHNH}^{+}+\mathrm{CH}_{3} \mathrm{NH}_{2}$ & 9 & - & 16 & $5 \pm 3$ & - & - & - \\
\hline
\end{tabular}

\footnotetext{
${ }^{9}$ Photoionization mass spectrometer, at $11.5 \mathrm{eV}$

Drift tube experiments.

clon cyclotron resonance mass spectrameter.
}

subsequent measurements of its disappearance with a variable time delay allowed determination of the rate constants. The pulse sequence used in the present experiments is shown in Figure 1.

Methylamine, dimethylamine, and trimethylamine (Matheson) were of the best available purity $(-99 \%)$ and were used without further purification.

The numerical simulation written by L. P. A. Robichaud [14] to find solutions for a system of first-, second-, and/or third-order kinetic differential equations was used to calculate the rate constants of proton or charge transfer processes in the mixtures of methylamines. In order to run this program the initial concentrations (at $t=0$ ) must be known and a reaction mechanism and initial rate constants must be assumed. The initial concentrations of neutral reactants are known from the total pressure and the mixture ratios. Since the absolute initial concentration of the primary ion species is not known, it was arbitrarily chosen to be $1 \%$ of the neutral concentration, which is small enough to maintain the concentration of neutral reactants at a constant level during the experimental reaction time. If more realistic values of $0.1 \%$ or $0.01 \%$ for the initial concentration of primary ion species were used, the calculation time increases correspondingly without changing the results.

The accuracy of the values of the rate constants determined depends heavily on the chemical sensitivity of the ionization gauge [15]. The Bartmess relation ( $R_{x}=0.36 \alpha+0.30, \alpha$ being the polarizability) was used to correct the pressure reading for pure gases [16]. However, in the case of gas mixtures no empirical relation exists that could help us establish the real pressure in the ICR cell; therefore, as a first approximation, a weighted-average value for the corrected pressure of the mixture was used. We expect that rate constant values are accurate to within $10 \%$ for reactions $2-5$, but only within $20 \%$ for all reactions whose rates have been obtained via numerical simulation for ion-molecule processes in mixtures.

\section{Results and Discussion}

The selectively isolated molecular ion $\mathrm{CH}_{3} \mathrm{NH}_{2}^{+}(\mathrm{m} / \mathrm{z}$ 31 ) is observed to react with monomethylamine only by proton transfer process:

$$
\mathrm{CH}_{3} \mathrm{NH}_{2}^{+}+\mathrm{CH}_{3} \mathrm{NH}_{2} \rightarrow \mathrm{CH}_{3} \mathrm{NH}_{3}^{+}+\mathrm{CH}_{2} \mathrm{NH}_{2} \text {. }
$$

The selectively isolated fragment ion $\mathrm{CH}_{2} \mathrm{NH}_{2}^{+}$ ( $m / z=30$ ) reacts with neutral monomethylamine also only by proton transfer:

$$
\mathrm{CH}_{2} \mathrm{NH}_{2}^{+}+\mathrm{CH}_{3} \mathrm{NH}_{2} \rightarrow \mathrm{CH}_{3} \mathrm{NH}_{3}^{+}+\mathrm{CH}_{3} \mathrm{~N} \cdot
$$

This thus allows a straightforward measurement of the rate constants of proton transfer (reactions 4 and 5) from the pseudo furst-order disappearance reactions of the reacting ions $m / z 31$ and 30 .

In the case of $m / z 28,\left[\mathrm{C}, \mathrm{N}, \mathrm{H}_{2}\right]^{+}$, ion reacting with monomethylamine two ionic products were formed (reactions $6 a$ and $b$ ), the most abundant being the protonated methylamine ion, $m / z$ 32, the other being $m / z$ 30. Nitrogen protonated $\mathrm{HCN}_{r}$ $\left(\mathrm{HC}=\mathrm{NH}^{+}\right)$, should react at the collision rate with $\mathrm{CH}_{3} \mathrm{NH}_{2}$ to yield protonated methylamine:

$$
\mathrm{HC} \equiv \mathrm{NH}^{+}+\mathrm{CH}_{3} \mathrm{NH}_{2} \rightarrow \mathrm{CH}_{3} \mathrm{NH}_{3}^{+}+\mathrm{CHN}
$$

It is therefore tempting to ascribe the $10 \%$ of reaction that gives $\mathrm{CH}_{2} \mathrm{NH}_{2}^{+}(m / z 30)$ to a hydride transfer process by another ionic structure. The most probable possibility would seem to be $\mathrm{H}_{2} \mathrm{C}=\mathrm{N}^{+}$, which upon hydride abstraction would give a stable methylene imine neutral product:

$$
\mathrm{H}_{2} \mathrm{C}=\mathrm{N}^{+}+\mathrm{CH}_{3} \mathrm{NH}_{2} \rightarrow \mathrm{CH}_{2} \mathrm{NH}_{2}^{+}+\mathrm{CH}_{2}=\mathrm{NH}
$$

The variation of experimental intensities as a function of reaction time and the calculated curves (solid and dashed lines) obtained through numerical simulation of the kinetic differential equations are shown in Figure 2. The rate constants derived are given in Table 2.

Ion-molecule reactions of selectively isolated

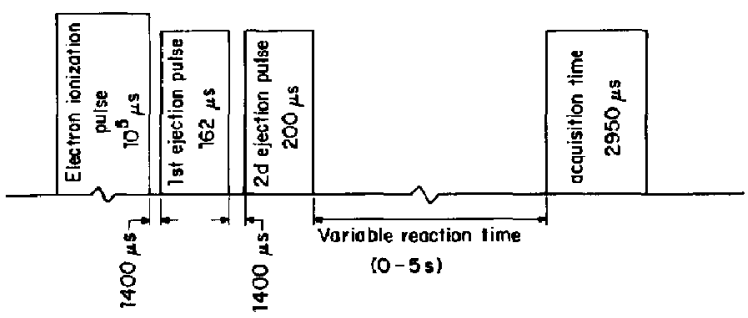

Figure 1. Pulse sequence used to observe the reactions of the isolated ion species. 


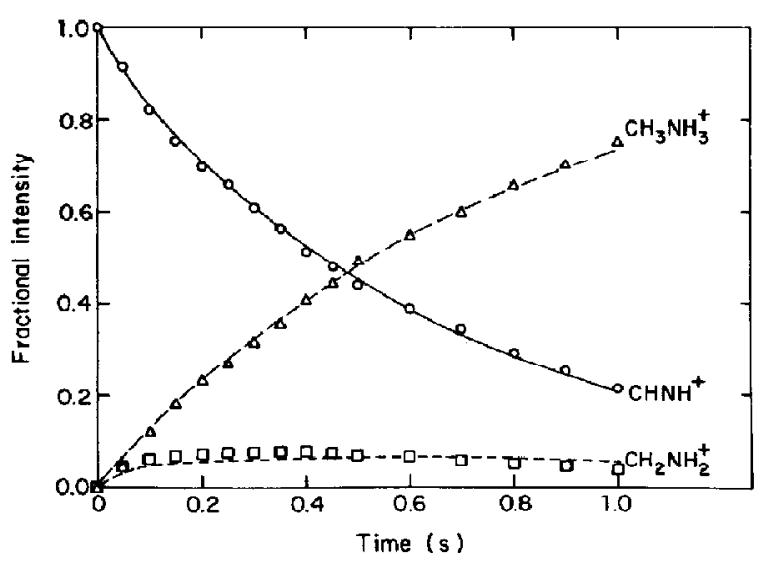

Figure 2. Temporal variation of ion species formed in reaction between $\mathrm{CHNH}^{+}$and methylamine. The lines were calculated by assuming rate constants in Table 2 .

$\mathrm{CH}_{3} \mathrm{NH}_{3}^{+}(m / z$ 32) with dimethylamine were studied in a mixture of known ratio of monomethylamine and dimethylamine $(1.0: 0.13)$. The only product ion species formed in this system was the protonated dimethylamine ion $(m / z 46)$ and the obvinus reaction assumed to take place was reaction 2 . This pseudo first-order disappearance reaction of protonated methylamine $(m / z 32)$ allows an unambiguous measurement of the rate constant (Table 2). The agreement between the collision rate obtained by the trajectory calculation and the total experimental rate constants indicates that the gauge calibration is very likely excellent.

The reactions of selectively isolated $\mathrm{CH}_{3} \mathrm{NH}_{2}^{+}(\mathrm{m} / \mathrm{z}$ 31) in a methylamine and dimethylamine mixture could be followed in the same manner, but in this case three product ion species were formed: $\mathrm{CH}_{3} \mathrm{NH}_{3}^{+}$ $\left(m / z\right.$ 32), $\left(\mathrm{CH}_{3}\right)_{2} \mathrm{NH}^{+}(m / z 45)$, and $\left(\mathrm{CH}_{3}\right)_{2} \mathrm{NH}_{2}^{+}$ $(m / z 46)$, which are assumed to be formed by reactions $2,4,7,8$, and 9 :

$$
\begin{aligned}
\mathrm{CH}_{3} \mathrm{NH}_{2}^{+}+\left(\mathrm{CH}_{3}\right)_{2} \mathrm{NH} & \rightarrow\left(\mathrm{CH}_{3}\right)_{2} \mathrm{NH}^{+}+\mathrm{CH}_{3} \mathrm{NH}_{2} \\
& \rightarrow\left(\mathrm{CH}_{3}\right)_{2} \mathrm{NH}_{2}^{+}+\mathrm{CH}_{2} \mathrm{NH}_{2}
\end{aligned}
$$

$$
\left(\mathrm{CH}_{3}\right)_{2} \mathrm{NH}^{+}+\left(\mathrm{CH}_{3}\right)_{2} \mathrm{NH} \rightarrow\left(\mathrm{CH}_{3}\right)_{2} \mathrm{NH}_{2}+\left(\mathrm{CH}_{3}\right)_{2} \mathrm{~N} \cdot
$$

which are all exothermic. The knowledge of the rate constants (Table 2) of the proton transfer processes 2 and 4 allows the calculation of the rate constants of the charge transfer (reaction 7), and of the proton transfer in reaction 8 . In addition, the proton transfer in reaction 9 between dimethylamine ions $(m / z 45)$ and neutral dimethylamine had to be taken into account to accurately model the intensities. The calculated rate constants for these reactions are also given in Table 2. By using these values the calculated disappearance or formation curves can be compared with experimental data as shown in Figure 3 . The fit is seen to be satisfactory within the experimental errors of the rate constant assignments.

The reaction of selectively isolated $\mathrm{CH}_{2} \mathrm{NH}_{2}^{+}(\mathrm{m} / z$ 30 ) in a mixture of methylamine/dimethylamine $(1.0: 0.13)$ leads to the formation of two product ions: $\mathrm{CH}_{3} \mathrm{NH}_{3}^{+}(m / z 32)$ and $\left(\mathrm{CH}_{3}\right)_{2} \mathrm{NH}_{2}^{+}(m / z 46)$. The assumption that these ion products are formed in reactions 2 and 5 only is erroneous as shown in Figure 4 by the fact that the calculated curves (dashed lines) do not fit the experimental points. In order to get a satisfactory fit between calculated curves and the experimental data it is necessary to assume an additional proton transfer reaction from $\mathrm{m} / \mathrm{z} 30$ ion species to dimethylamine:

$$
\mathrm{CH}_{2} \mathrm{NH}_{2}^{+}+\left(\mathrm{CH}_{3}\right)_{2} \mathrm{NH} \rightarrow\left(\mathrm{CH}_{3}\right)_{2} \mathrm{NH}_{2}^{+}+\mathrm{CH}_{2} \mathrm{NH} \cdot
$$

\begin{tabular}{|c|c|c|}
\hline \multirow[b]{2}{*}{ Reaction } & \multicolumn{2}{|c|}{$k\left(\mathrm{~cm}^{3} \mathrm{~s}^{-1}\right) \times 10^{10}$} \\
\hline & Experimental & $\begin{array}{c}\text { Trajectory } \\
\text { calculation [1 } 11]\end{array}$ \\
\hline $\mathrm{CH}_{3} \mathrm{NH}_{2}^{+}+\mathrm{CH}_{3} \mathrm{NH}_{2} \rightarrow \mathrm{CH}_{3} \mathrm{NH}_{3}^{+}+\mathrm{CH}_{2} \mathrm{NH}_{2}$ & $18.8 \pm 1.9$ & 20.2 \\
\hline $\mathrm{CH}_{2} \mathrm{NH}_{2}^{+}+\mathrm{CH}_{3} \mathrm{NH}_{2} \rightarrow \mathrm{CH}_{3} \mathrm{NH}_{3}^{+}+\mathrm{CH}_{2} \mathrm{NH}$ & $15.9 \pm 1.6$ & 20.4 \\
\hline$\left[\mathrm{CH}_{2} \mathrm{~N}\right]^{+}+\mathrm{CH}_{3} \mathrm{NH}_{2} \rightarrow \mathrm{CH}_{3} \mathrm{NH}_{3}^{+}+\mathrm{CHN}$ & $18.9 \pm 1.9$ & 20.8 \\
\hline$\rightarrow \mathrm{CH}_{2} \mathrm{NH}_{2}^{+}+\mathrm{CH}_{3} \mathrm{~N}$ & $2.4 \pm 0.4$ & \\
\hline $\mathrm{CH}_{3} \mathrm{NH}_{3}^{+}+\left(\mathrm{CH}_{3}\right)_{2} \mathrm{NH} \rightarrow\left(\mathrm{CH}_{3}\right)_{2} \mathrm{NH}_{2}^{+}+\mathrm{CH}_{2} \mathrm{NH}_{2}$ & $16.1 \pm 1.6$ & 17.5 \\
\hline $\mathrm{CH}_{3} \mathrm{NH}_{2}^{+}+\left(\mathrm{CH}_{3}\right)_{2} \mathrm{NH} \rightarrow\left(\mathrm{CH}_{3}\right)_{2} \mathrm{NH}^{+}+\mathrm{CH}_{3} \mathrm{NH}_{2}$ & $9.3 \pm 1.8$ & 17.6 \\
\hline$\rightarrow\left(\mathrm{CH}_{3} \mathrm{I}_{2} \mathrm{NH}_{2}^{+}+\mathrm{CH}_{2} \mathrm{NH}_{2}\right.$ & $7.7 \pm 1.4$ & \\
\hline $\mathrm{CH}_{2} \mathrm{NH}_{2}^{+}+\left(\mathrm{CH}_{3}\right\}_{2} \mathrm{NH} \rightarrow\left\{\mathrm{CH}_{3}\right)_{2} \mathrm{NH}_{2}^{+}+\mathrm{CH}_{2} \mathrm{NH}$ & $16.4 \pm 1.7$ & 17.8 \\
\hline$\left(\mathrm{CH}_{3}\right)_{2} \mathrm{NH}^{+}+\left(\mathrm{CH}_{3}\right)_{2} \mathrm{NH} \rightarrow\left(\mathrm{CH}_{3}\right)_{2} \mathrm{NH}_{2}^{+}+\left(\mathrm{CH}_{3}\right)_{2} \mathrm{~N}$ & $13.0 \pm 2.6$ & 15.9 \\
\hline $\mathrm{CH}_{3} \mathrm{NH}_{3}^{+}+\left(\mathrm{CH}_{3}\right)_{3} \mathrm{~N} \rightarrow\left(\mathrm{CH}_{3}\right)_{3} \mathrm{NH}^{+}+\mathrm{CH}_{3} \mathrm{NH}_{2}$ & $9.3 \pm 0.9$ & 15.7 \\
\hline $\mathrm{CH}_{3} \mathrm{NH}_{2}^{+}+\left(\mathrm{CH}_{3}\right\}_{3} \mathrm{~N} \rightarrow\left(\mathrm{CH}_{3}\right)_{3} \mathrm{~N}^{+}+\mathrm{CH}_{2} \mathrm{NH}_{3}$ & $15.0 \pm 5.0$ & 15.9 \\
\hline$\rightarrow\left(\mathrm{CH}_{3}\right)_{3} \mathrm{NH}^{+}+\mathrm{CH}_{2} \mathrm{NH}_{2}$ & $1.3 \pm 0.4$ & \\
\hline$\left(\mathrm{CH}_{3}\right)_{3} \mathrm{~N}^{+}+\left(\mathrm{CH}_{3}\right)_{3} \mathrm{~N} \rightarrow\left(\mathrm{CH}_{3}\right)_{3} \mathrm{NH}^{+}+\left(\mathrm{CH}_{3}\right)_{2} \mathrm{NCH}_{2}$ & $11.1 \pm 3.3$ & 13.2 \\
\hline
\end{tabular}

Table 2. Rate constants for reactions between methylamines, dimethylamines and trimethylamines 


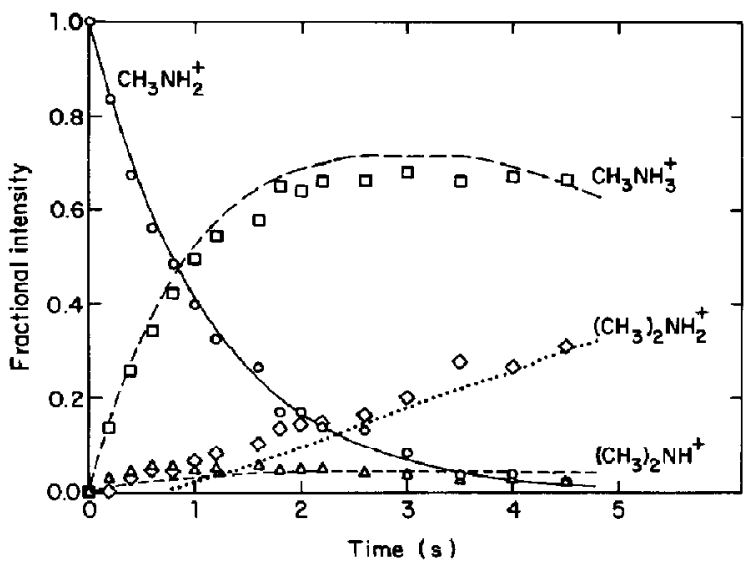

Figure 3. Temporal variation of ion species formed in reaction of $\mathrm{CH}_{3} \mathrm{NH}_{2}^{+}$in methylamine/dimethylamine $(1,0 ; 0,13)$ mixture. The lines were calculated by assuming the rate constants in Table 2.

The rate constant for reaction 10 is given in Table 2 , and the calculated variations of ion intensities involved in reactions 2,5 , and 10 are displayed as solid lines in Figure 4.

The same experimental approach was repeated for measurements of the charge and proton transfer processes between monomethylamine ions and trimethylamine, where a mixture of known ratio of $\mathrm{CH}_{3} \mathrm{NH}_{2}$ and $\left(\mathrm{CH}_{3}\right)_{3} \mathrm{~N}(1.0: 0.09)$ was used.

The selectively isolated $\mathrm{CH}_{3} \mathrm{NH}_{3}^{+}(m / z \quad 32)$ ion species reacts with trimethylamine in a proton transfer process only (reaction 3). The pseudo first-order kinetics of reaction 3 allows a precise determination of the rate constant, which is given in Table 2.

On the other hand, the $\mathrm{CH}_{3} \mathrm{NH}_{2}^{+}(m / z 31)$ reacts

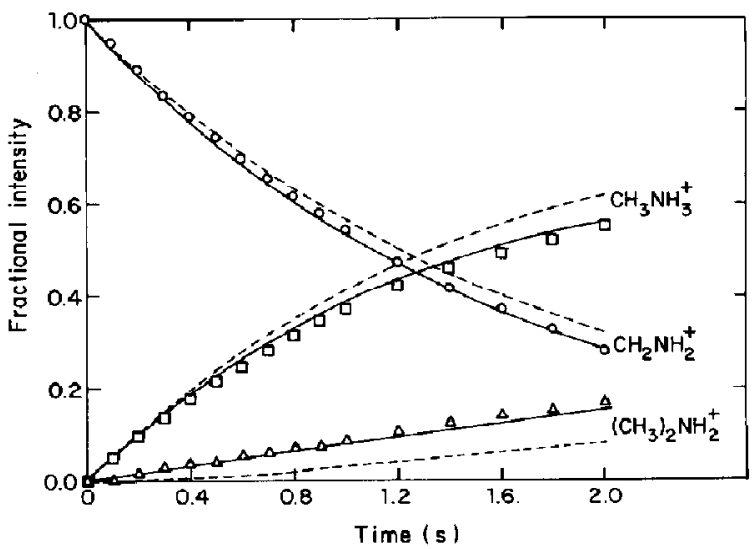

Figure 4. Temporal variation of ion species formed in reaction of $\mathrm{CH}_{2} \mathrm{NH}_{2}^{+}$in methylamine/dimethylamine (1.0:0.13) mixture. The dashed lines were calculated by assuming that only reactions 2 and 5 are responsible for the production formation, whereas the solid lines were calculated by assuming reactions 2 , 5 , and 10 , respectively. with both neutral methylamine and trimethylamine giving the ion products $\mathrm{CH}_{3} \mathrm{NH}_{3}^{+}(\mathrm{m} / z$ 32), $\left(\mathrm{CH}_{3}\right)_{3} \mathrm{~N}^{+}(m / z 59)$, and $\left(\mathrm{CH}_{3}\right)_{3} \mathrm{NH}^{+}(m / z 60)$. Obviously, the protonated methylamine ion $(m / z 32)$ formed in reaction 4 reacts further with trimethylamine in reaction 3 , while trimethylamine molecular ion $(m / z 59)$ is formed in a charge transfer process from ionized methylamine:

$$
\mathrm{CH}_{3} \mathrm{NH}_{2}^{+}+\left(\mathrm{CH}_{3}\right)_{3} \mathrm{~N} \rightarrow\left(\mathrm{CH}_{3}\right)_{3} \mathrm{~N}^{+}+\mathrm{CH}_{3} \mathrm{NH}_{2}
$$

However, an additional channel for the formation of protonated trimethylamine is an exothermic (by 22 $\mathrm{kcal} /$ mole) proton transfer from $\mathrm{CH}_{3} \mathrm{NH}_{2}^{+}(m / z 31)$ to neutral trimethylamine:

$$
\mathrm{CH}_{3} \mathrm{NH}_{2}^{+}+\left(\mathrm{CH}_{3}\right)_{3} \mathrm{~N} \rightarrow\left(\mathrm{CH}_{3}\right)_{3} \mathrm{NH}^{+}+\mathrm{CH}_{2} \mathrm{NH}_{2} \text {. }
$$

This must be taken into account in numerical simulation.

As in the previous case, a proton transfer between trimethylamine molecular ion $(m / z 59)$ and neutral trimethylamine must be assumed to complete the possible exothermic reactions occurring in the system:

$$
\left(\mathrm{CH}_{3}\right)_{3} \mathrm{~N}^{+}+\left(\mathrm{CH}_{3}\right)_{3} \mathrm{~N} \rightarrow\left(\mathrm{CH}_{3}\right)_{3} \mathrm{NH}^{+}+\left(\mathrm{CH}_{3}\right)_{2} \mathrm{NCH}_{2} .
$$

The knowledge of the proton transfer rate constants (reactions 3 and 4) allows the calculation of the rate constants of reactions $11-13$. The results are given in Table 2.

The low fractional intensities of $\left(\mathrm{CH}_{3}\right)_{3} \mathrm{NH}^{+}(\mathrm{m} / z$ 59) and $\left(\mathrm{CH}_{3}\right)_{3} \mathrm{NH}^{+}(m / z 60)$ formed in reactions 11 , 12 , and 13 make the numerical simulation less sensitive to the assumed rate constant values, and therefore, the uncertainty in these values in Table 2 is higher than that in similar reactions (7-9) in the methylamine/dimethylamine system. We estimate the uncertainty of rate constant values of reactions 11-13 at about $30 \%$.

The experimentally measured rate constant for the proton transfer process from the molecular methylamine ion $(m / z$ 31) to neutral methylamine in reaction 4 agrees well with the values published by Jones and Harrison [4] and Barassin et al. [7], which were obtained in a high-pressure mass spectrometer and a drift tube, respectively, and is higher by around 15\% than the value of McMahon and Beauchamp [8] obtained in an ICR instrument. It also compares satisfactorily with the ion-polar molecule collision rate constant obtained by trajectory calculation [11] (Table 2). We believe that measuring the rate constants in a high-pressure mass spectrometer, where individual contributions from molecular and fragment ions to product ions are not easily unraveled, accounts for the discrepancies shown in Table 1. 


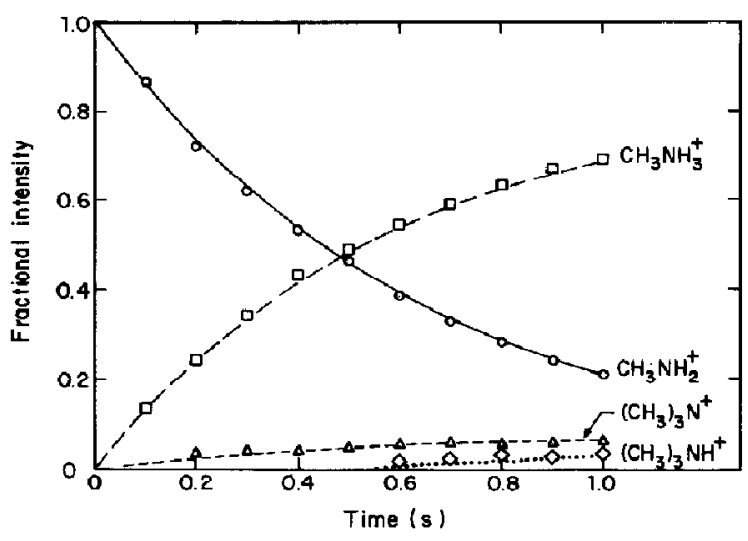

Figure 5. Temporal variation of ion species formed in reaction of $\mathrm{CH}_{3} \mathrm{NH}_{2}^{+}$in methylamine/trimethylamine (1.0:0.09) mixture. The lines were calculated by assuming the rate constants in Table 2.

Our rate constant value for reaction 5 suggests that proton transfer occurs at or near collision rate, which is quite reasonable.

The same argument applies to the reaction of $\left[\mathrm{C}, \mathrm{N}, \mathrm{H}_{2}\right]^{+}(\mathrm{m} / \mathrm{z} 28)$ ions with methylamine where two product ions are formed, with one of them, $\mathrm{m} / \mathrm{z}$ 31, reacting further with neutral methylamine. The advantage of using the selective ejection technique is clearly seen in this case. It was previously reported that this ion reacts only in a proton transfer process (reaction 6a) $[2,4,5]$, but present results reveal that a less energetically favored hydride transfer process characterized by a relatively low rate constant is also taking place. Obviously, in a high-pressure mass spectrometer where many reacting ions are simultaneously present in the collision cell, the unraveling of complex kinetics is sometimes impossible, and the simplified kinetic models assumed do not necessarily give conclusive results.

As expected, the proton transfer process from $\mathrm{CH}_{3} \mathrm{NH}_{3}^{+}$( $m / z$ 32) to dimethylamine (reaction 2) is a very fast reaction occurring, within experimental error, at or near collision rate (Table 2). The molecular methylamine ion ( $m / z 31$ ) reacts with dimethylamine at the collision rate with almost equal probability in two reaction channels: charge and proton transfer processes (reactions 7 and 8).

The proton transfer in reaction 3 between the protonated methylamine ion $(m / z \quad 32)$ and trimethylamine occurs at about $60 \%$ of the collision rate, which indicates that some steric effects might play a role in proton transfer between the reactants.

In the case of the reaction between methylamine molecular ion $(\mathrm{m} / \mathrm{z} 31$ ) and trimethylamine (reactions 11 and 12) in the methylamine/trimethylamine system, the situation is reversed compared to that of the methylamine/dimethylamine system. Here, due to the greater difference in ionization energies, the fastest reaction is the charge transfer process from $\mathrm{CH}_{3} \mathrm{NH}_{2}^{+}$ to $\left(\mathrm{CH}_{3}\right)_{3} \mathrm{~N}$, while the proton transfer $(12)$ is about one order of magnitude slower. This results in the greater abundance of $m / z 59$ than of $m / z 60$ in Figure 5. However, in order to get a reasonable fit between experimental results and the numerical simulation in both systems, methylamine/dimethylamine and methylamine/trimethylamine, it is necessary to assume that the additional fast proton transfer processes ( 9 and 13) occur at nearly the collision rate (Table 2). It is known that charge transfer competes with proton transfer when differences in the ionization potentials of the reactants make such process exothermic, which is the case for these systems. The present results thus support conclusions drawn in earlier mass spectrometric and radiolysis studies of $\mathrm{C}_{4} \mathrm{H}_{8}^{+}$species with methylamines $[17,18]$.

\section{Conclusion}

The above experiments reveal the power of the FT-ICR techniques in unraveling the complex kinetics and mechanistic details of parallel and sequential reactions in mixtures. The selective ion ejection technique greatly simplifies such elucidations, which are ultimately validated by the use of the kinetic numerical simulation.

The present results show that the rate constants of proton transfer from molecular ions of methylamines, $\left(\mathrm{CH}_{3}\right)_{n} \mathrm{NH}_{3-n}^{+}(n=1-3)$, to their own neutral species are near the collision rate. On the other hand, while the rate constant of proton transfer from $\mathrm{CH}_{3} \mathrm{NH}_{3}^{+}$ ( $m / z$ 32) to dimethylamine seems to be near the collision rate, it drops to around $60 \%$ when reacting with trimethylamine. In addition to proton transfer reactions, charge transfer processes occur from methylamine molecular ion ( $\mathrm{m} / \mathrm{z} 31$ ) to di- and trimethylamines, which complicates the kinetics of these systems.

The ion-molecule reactions observed in methylamine and dimethylamine and trimethylamine systems have to be taken into consideration when measurements of slower rate constants of nucleophilic substitution in these systems are to be studied. The data in this article provide the means to do this quantitatively.

\section{Acknowledgment}

The financial assistance of the National Sciences and Engineering Research Council of Canada is gratefully acknowledged.

\section{References}

1. Xu, G.; Herman, J. A.; Wojeik, L. Can. J. Chem. 1990, 68, 570.

2. Munson, M. S. B. J. Phys. Chem. 1966, 70, 2034.

3. Henchman, M. Disc. Faraday Soc. 1965, 39, 63. 
4. Jones, E. G.; Harrison, A. G. Can. J. Chem. 1967, 45, 3119.

5. Zielinska, T. J.; Wincel, H. Nukleonika 1970, 15, 343.

6. Hellner, L.; Sieck, L. W. Int. I. Chem. Kinetics 1973, 5, 177.

7. Barassin, J.; Barassin, A.; Thomas, R. Int. J. Mass Spectrom. lon Phys. 1983, 49, 51.

8. McMahon, T. B.; Beauchamp, J. L. J. Phys. Chem. 1977, 81, 593.

9. Bupbacher, J. M.; Eagle, C. J.; Tschuikow-Roux, E. I. Phys. Chem. 1975, 79, 671.

10. Bohme, D. K. In Interactions between Ions and Molecutes; Ausloos, P., Ed.; Plenum: New York, 1975; pp. 489-504.

11. Su, T.; Chesnavich, W. J. J. Chem. Phys. 1982, 76, 5183.
12. Alleman, M.; Kellerhalls, H.; Wanczek, K. P. Int. J. Mass Spectrom. Ion Processes 1983, 46, 139.

13. Kofel, P.; McMahon, I. B. Int. J. Mass Spectrom. Ion Processes $1990,98,1$.

14. Robichaud, L. P. Research report, DIUL-RR, Laval University, to be published.

15. Dushman, S. Scientific Foundation of Vacuum Technique, 2nd ed.; J. Wiley: New York, 1962; pp. 301-350.

16. Bartmess, J. E.; Georgiadis, R. M. Vacuum 1983, 33, 149.

17. Hughes, B. M.; Tiernan, T. O. J. Chem. Phys. 1969, 51, 4373.

18. Doepker, R. D.; Ausloos, P. J. Chem. Phys. 1966, 44, 1641. 